\title{
APLIKASI MAP; EFEKTIVITAS MATLAB ALGORITM PROGRAM UNTUK MENINGKATKAN KETERAMPILAN LOGIC PHYSICS MAHASISWA
}

\author{
Johri Sabaryati ${ }^{*}$, Zulkarnain ${ }^{2}$ \\ ${ }^{1 * 2}$ Program Studi Pendidikan Fisika, FKIP Univesitas Muhammadiyah Mataram \\ ${ }^{*}$ Corresponding author: \\ Email: joyafarashy@gmail.com
}

Diterima 8 Mei 2019, Disetujui 14 Mei 2019

\begin{abstract}
ABSTRAK
Penelitian bertujuan untuk menguji efektivitas aplikasi Matlab Algoritm program (MAP) untuk meningkatkan keterampilan Logic Physics mahasiswa. Metode yang digunakan dalam penelitian ini adalah Pre Experimental Design dengan model One-Group Pretest-Posttes Design. Teknik analisis data menggunakan pre test dan post test menggunakan rumus Uji $\mathrm{N}$ gain. Bahan ajar ini sebelumnya divalidasi oleh ahli, berdasarkan validasi ahli produk yang bahan ajar sudah layak digunakan. Uji coba produk dilakukan di Mahasiswa semester VI Program Studi Pendidikan Fisika Fakultas Keguruan dan IImu Pendidikan Universitas Muhammadiyah Mataram Tahun Akademik 2018/2019 dengan nilai gain 0,31 berada pada kategori sedang.
\end{abstract}

Kata Kunci: Matlab Algoritm, Logic Physics.

\section{PENDAHULUAN}

Pada era persaingan bebas ini, Pemerintah memerlukan Sumber Daya Manusia (SDM) yang berkualitas, yaitu manusia cerdas, sehat, jujur, berakhlak mulia, berkarakter, memiliki kepedulian sosial tinggi serta mampu beradaptasi dengan perkembangan IImu Pengetahuan Teknologi dan Seni (IPTEKS). Peningkatan kualitas pendidikan adalah kunci utama untuk pengembangan SDM dan pembentukan karakter dalam menentukan nasib bangsa (Nas, 2005). Berbagai upaya telah dilakukan oleh pemerintah untuk meningkatkan kualitas pendidikan di Indonesia. Upaya-upaya yang telah dilakukan oleh pemerintah diantaranya, perubahan kurikulum, peningkatan kesejahteraan guru dan dosen, perbaikan sarana dan prasarana pendidikan, mengadakan sertifikasi untuk penjaminan mutu pengajar, mengadakan seminar-seminar nasional bidang pendidikan, serta berbagai upaya lainnya.

Harapan ini ternyata tidak sesuai dengan kenyataan yang dialami oleh mahasiswa-mahasiswa di Program Studi Fisika Universitas Muhammadiyah. Indikasi ini berawal dari cukup banyaknya mahasiswa yang mengalami kesulitan menyelesaikan masalah terkait konsep berlogika dalam fisika. Terlebih lagi mereka sebagai calon guru fisika yang harus memahami dan kuat dalam analisis dan berlogika dalam menyelesaikan berbagai permasalahan konsep dan teori fisika. Dari fakta ini terungkap adanya kesenjangan antara keterampilan logic physics mahasiswa untuk menyelesaikan permasalahan analisis dalam fisika komputasi. Setelah ditelusuri lebih mendalam, ternyata sebagian besar mahasiswa program studi fisika menunjukkan aktivitas belajar yang relatif rendah pada mata kuliah fisika komputasi terutama memahami kemampuan menyelesaikan persoalan logika setelah memiliki kemampuan dalam analisis. Faktafakta ini secara tidak langsung telah menunjukkan adanya kesenjangan antara harapan pemerintah mengenai peningkatan kualitas pendidikan terutama mahasiswa fisika sebagai seorang calon pengajar fisika. Adanya kesenjangan antara harapan dan kenyataan ini menggugah keinginan peneliti untuk menyelidiki lebih jauh permasalahan yang dialami mahasiswa program studi fisika Universitas Muhammadiyah Mataram.

Berdasarkan hasil studi awal yang telah dilakukan terhadap keterampilan berlogika mahasiswa, Rendahnya keterampilan berlogika dan aktivitas belajar mahasiswa sebagian besar disebabkan oleh rendahnya kualitas pembelajaran fisika terutama fisika komputasi yang sangat menuntut kemampuan berlogika mahasiswa. Hal ini didapatkan dari hasil refleksi diri yang dilakukan oleh pengajar terhadap kualitas pembelajaran sebelumnya. Pertama, berdasarkan hasil refleksi diri diketahui bahwa dalam pembelajaran dosen menggunakan strategi pembelajaran kooperatif dan siklus belajar, namun ternyata belum semua mahasiswa terlibat dalam proses pembelajaran. Hal ini disebabkan karena ketidak-konsistenan pengajar 
dalam menerapkan strategi tersebut. Permasalahan tersebut teramati saat pembelajaran, hanya sebagian kecil mahasiswa yang mau berpartisipasi dalam proses pembelajaran. Sedangkan mahasiswa yang lain lebih berperan sebagai pendengar dari pada partisipan. Kedua, rendahnya pemahaman mahasiswa terhadap pemahaman analisis teori serta rendahnya aktivitas belajar mahasiswa, yang dikarenakan pembelajaran masih mengandalkan penjelasan dari dosen tanpa adanya buku panduan, walaupun dalam pembelajaran sudah menggunakan kelompok-kelompok belajar. Proses aktif mahasiswa dalam merekonstruksi pengetahuan melalui kegiatan penugasan juga jarang dilakukan. Padahal fisika komputasi sangat menuntut mahasiswa untuk memahami proses dan produk, bukan hanya produk semata. Rendahnya pemahaman analisis mahasiswa akan membuat keterampilan berlogika fisika mahasiswa juga menjadi rendah.

Pada tahun akademik 2017/2018, berdasarkan hasil evaluasi pengajaran yang dilakukan dan diskusi dengan pak Zulkarnain, M.Si. Pengajar belum melaksanakan kegiatan yang benarbenar menantang mahasiswa untuk belajar. Kegiatan belajar yang selama ini dilakukan hanya sebatas di kelas saja. Pengajar belum memiliki inovasi yang baik dalam melakukan teknik pembelajaran sehingga mahasiswa menjadi cenderung pasif di kelas. Pengajar belum memberikan ruang bagi mahasiswa unutk melakukan kompetisi dan tantanan yang baik bagi mahasiswa. Sehingga dengan penerapan aplikasi Matlab Algoritm diharapkan dapat meningkatkan aktivitas serta kemampuan keterampilan berlogika fisika mahasiswa.

Berdasarkan uraian tersebut, maka dapat dikatakan bahwa rendahnya keterampilan berlogika fisika dan aktivitas belajar mahasiswa di program studi fisika terutama pada mata kuliah fisika komputasi dikarenakan pembelajaran belum mengadopsi keinginan mahasiswa untuk belajar, perngajar belum menggunakan model pembelajaran yang inovatif, dan kurang memberikan tantangan bagi mahasiswa dalam belajar. Salah satu media pembelajaran yang dapat mengakomodasi keterampilan berlogika dan aktivitas belajar mahasiswa adalah penerapan aplikasi Matlab Algoritm Program (MAP). Aplikasi ini dipandang sebagai aplikasi yang cocok untuk menanggulangi permasalahan rendahnya keterampilan berlogika dan aktivitas belajar mahasiswa karena aplikasi ini mengintegrasikan komputasi, visualisasi, dan pemrograman dalam suatu model yang sangat mudah untuk pakai dimana masalah-masalah dan penyelesaiannya diekspresikan dalam notasi matematika yang familiar. Berdasarkan latar belakang masalah tersebut, maka peneliti merasa perlu melakukan suatu penelitian berupa efektivitas aplikasi MAP (Matlab Algoritm Program) dalam pembelajaran mata kuliah fisika komputasi untuk meningkatkan aktivitas dan keterampilan berlogika mahasiswa Program Studi Fisika Universitas Muhammadiyah Mataram Tahun Akademik 2018/2019.

\section{METODE PENELITIAN}

Jenis metode yang digunakan dalam penelitian ini adalah metode eksperimen. Dalam penelitian ini bentuk desain yang digunakan adalah desain Pre-Eksperimen. Dalam penelitian ini yang digunakan adalah One-Group Pretest-Posttest Design dimana terdapat Pretest sebelum perlakuan dan Posttest setelah perlakuan. Intrumen penelitian ini berupa angket dan soal serta lembar validasi ahli.

Penelitian ini meliputi tiga tahap yaitu tahap persiapan penelitian, tahap pelaksanaan penelitian, dan tahap akhir penelitian. Adapun alur penelitian tampak sebagai berikut:

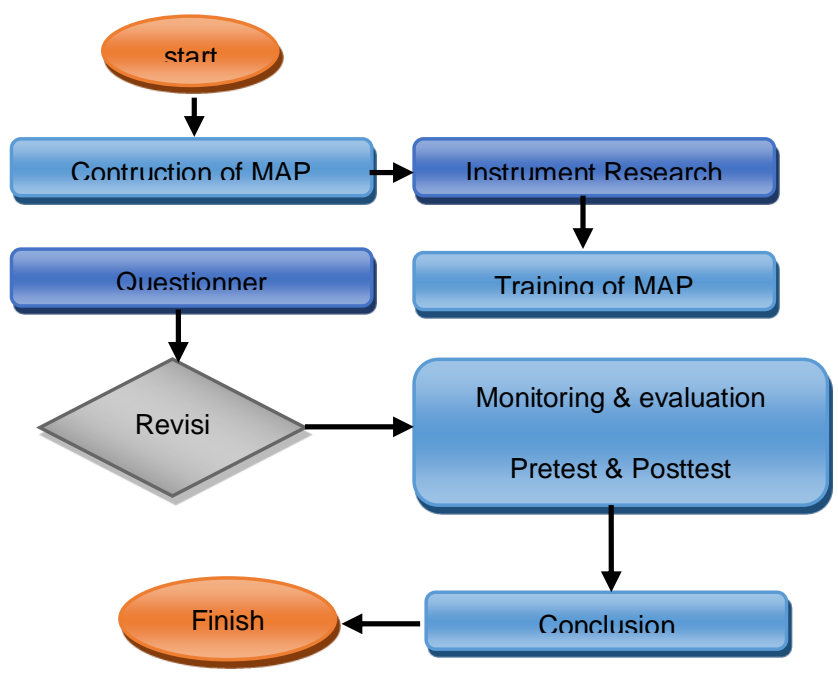

Gambar 1. Alur penelitian

Teknik analisis data merupakan suatu cara untuk mengolah data hasil penelitian guna memperoleh suatu kesimpulan. Dimana penelitian ini lebih menitik beratkan pada efektivitas Matlab Algoritm untuk meningktkan keterampilan Logic Physics Mahasiswa Semeter VI program studi pendidikan fisika FKIP Universitas Muhammadiyah Mataram Tahun Akademik 2018/2019. Adapun uji persyaratan analisis data adalah sebagai berikut: 


\section{Uji N-gain}

Gain adalah selisih antara nilai pretest dan posttes. Gain menunjukan efektivitas Matlab Algoritm untuk meningkatkan keterampilan logic Physics mahasiswa setelah pembelajaran dilakukan.

$$
\text { gain }=\frac{S_{\text {post }}-S_{\text {pre }}}{S_{\max }-S_{\text {pre }}}
$$

Keterangan:

g(gain) = gain

Spre = skor awal

Sost $=$ skor akhir

Data hasil perhitungan efektivitas Matlab Algoritm untuk meningkatkan keterampilan logic Physics mahasiswa sebelum dan sesudah, kemudian akan diiterpretasikan dengan menggunakan gain standar sebagai berikut:

Tabel 1. Nilai Indeks Gain Standar

\begin{tabular}{|l|l|}
\hline Nilai gain standar & Keterangan \\
\hline$\geq 0,7$ & Tinggi \\
\hline $0,7 \geq g \geq 0,3$ & Sedang \\
\hline$\leq 0,3$ & Rendah \\
\hline
\end{tabular}

(Hake, 1998 : 65)

Nilai Gain untuk mengetahu efektivitas Matlab Algoritm meningkatkan keterampilan logic Physics mahasiswa, maka bahan ajar dikatakan telah teruji keefektifannya.

\section{HASIL DAN PEMBAHASAN \\ Studi Pendahuluan}

a. Studi pustaka yaitu melakukan kajian literatur yang relevan dengan penelitian.

Studi pustaka dilakukan untuk mengumpulkan infomasi, diantaranya dengan mempelajari silabus mata kuliah dan rencana pelaksanaan pembelajaran yang disusun dosen yang berkaitan dengan karakteristik perkuliahan, alokasi waktu yang tersedia, kemudian membaca jurnal atau laporan hasil penelitian tentang pengembangan bahan ajar fisika komputasi. Selain itu juga diperlukan studi pustaka diperlukan untuk model-model pembelajaran dan penggunaan program computer dalam kegiatan pembelajaran fisika komputasi.

b. Survei lapangan sharing informasi tentang kegiatan pembelajaran fisika komputasi selama ini, potensi-potensi yang dimiliki, proses pembelajaran dan dokumen hasil belajar mahasiswa.

\section{Pengembangan Produk Awal}

Kegiatan ini adalah merancang bahan ajar solusi numerik logika fisika berbasis Matlab Algoritm, lembar validasi bahan ajar dan soal. Hasil rancangan awal ini dinamakan draft awal.

Bahan Ajar Solusi Numerik Logika Fisika Berbasis Matlab Algoritm

Kegiatan ini adalah untuk merancang produk Bahan Ajar Solusi Numerik Logika Fisika Berbasis Matlab Algoritm. Produk awal yang disusun terdiri dari beberapa bagian:

$\square$ Uraian materi

Berisi materi berbasis Scribs dan Gui Matlab. Landasan teori merupakan teori yang relevan yang digunakan untuk menjelaskan tentang Matlab dan cara penggunaannya.

Evaluasi

Evaluasi dalam produk Bahan Ajar Solusi Numerik Logika Fisika Berbasis Matlab Algoritm berisikan tentang pertanyaan yang mengarahkan peserta didik untuk dapat menjawab tujuan pembelajaran. Evaluasi yang dibuat juga dapat digunakan untuk mengukur peguasaan konsep yang telah diperoleh peserta didik

\section{Hasil Uji Produk}

\section{Data Hasil Validasi dan Penilaian Produk}

Data yang diperoleh dalam penelitian pengembangan Bahan Ajar Solusi Numerik Logika Fisika Berbasis Matlab Algoritm ini merupakan data hasil validasi yang dilakukan oleh ahli. Data hasil validasi dan penilaian juga dilengkapi dengan masukan serta komentar Bahan Ajar Solusi Numerik Logika Fisika Berbasis Matlab Algoritm dan Tes hasil belajar.

Tujuan validasi ahli adalah untuk memberikan nilai dan menentukan kelayakan dari bahan ajar yang telah dikembangkan. Validasi dan penilaian juga bertujuan untuk memperoleh komentar dan saran, baik secara tertulis maupun lisan dengan cara berdiskusi tentang Bahan Ajar Solusi Numerik Logika Fisika Berbasis Matlab Algoritm.

\section{a. Bahan Ajar Solusi Numerik Logika Fisika Berbasis Matlab Algoritm}

Validasi dan penilaian juga bertujuan untuk memperoleh komentar dan saran, baik secara tertulis maupun lisan dengan cara berdiskusi tentang Bahan Ajar Solusi Numerik Logika Fisika Berbasis Matlab Algoritm.

berikut.
Rekap hasil validasi oleh ahli pada tabel 2 
Tabel 2. Hasil penilaian bahan ajar oleh ahli

\begin{tabular}{|c|l|c|c|}
\hline No & \multicolumn{1}{|c|}{ Penilai } & Total & Skor \\
\hline 1 & Syaharudin, S.Pd, M.Si & 29 & $\mathrm{~A}$ \\
\hline 2 & Islahudin, S.Pd, M.Pfis & 30 & $\mathrm{~A}$ \\
\hline 3 & M.Isnaini, S.Pd, M.Pd & 31 & $\mathrm{~A}$ \\
\hline 4 & $\begin{array}{l}\text { Baiq Desi Milandari, } \\
\text { M.Pd. }\end{array}$ & 35 & $\mathrm{~A}$ \\
\hline 5 & $\begin{array}{l}\text { Ahyati Kurniamala N, } \\
\text { M.Pd. }\end{array}$ & 35 & $\mathrm{~A}$ \\
\hline
\end{tabular}

Berdasarkan pada tabel 2 tabel hasil penilaian ahli terhadap produk Bahan Ajar Solusi Numerik Logika Fisika Berbasis Matlab Algoritm layak untuk digunakan.

\section{Hasil Produk Akhir Hasil Uji coba Produk}

Untuk kemampuan solusi numerik logika mahasiswa, dapat dilihat dari data tes dan angket yang diberikan sebelum penggunaan produk (pretest) dan setelah penggunaan produk (posttest). Berikut data analisis respon mahasiswa dari angket yang diberikan.

Tabel 3. Data Analisis Respon mahasiswa Terhadap Penggunaan Bahan Ajar Solusi Numerik Logika Fisika

\begin{tabular}{|c|c|c|c|c|c|c|c|c|c|c|c|c|c|c|}
\hline \multirow{2}{*}{$\begin{array}{l}N \\
0\end{array}$} & \multirow{2}{*}{$\begin{array}{c}\text { Nam } \\
\text { a }\end{array}$} & \multicolumn{11}{|c|}{ Aspek yang dinilai } & \multirow{2}{*}{$\begin{array}{l}\mathrm{T} \\
\text { ot } \\
\text { al }\end{array}$} & \multirow{2}{*}{$\begin{array}{l}\mathrm{S} \\
\mathrm{k} \\
\mathrm{o} \\
\mathrm{r}\end{array}$} \\
\hline & & 1 & 2 & 3 & 4 & 5 & 6 & 7 & 8 & 9 & $\begin{array}{l}1 \\
0\end{array}$ & $\begin{array}{l}1 \\
1\end{array}$ & & \\
\hline 1 & $\begin{array}{l}\text { Juna } \\
\text { rdin }\end{array}$ & 3 & 3 & 4 & 4 & 4 & 3 & 3 & 4 & 3 & 4 & 3 & $\begin{array}{l}3 \\
8\end{array}$ & $A$ \\
\hline 2 & $\begin{array}{l}\text { Pra } \\
\text { ma } \\
\text { Arda } \\
\text { na }\end{array}$ & 3 & 4 & 4 & 4 & 4 & 3 & 3 & 3 & 4 & 3 & 3 & $\begin{array}{l}3 \\
8\end{array}$ & $A$ \\
\hline 3 & $\begin{array}{l}\text { Juria } \\
\text { tin }\end{array}$ & 3 & 3 & 4 & 4 & 4 & 3 & 4 & 3 & 4 & 4 & 4 & $\begin{array}{l}4 \\
0\end{array}$ & $A$ \\
\hline 4 & $\begin{array}{l}\text { Nurk } \\
\text { omar } \\
\text { iah }\end{array}$ & 3 & 3 & 3 & 3 & 3 & 2 & 3 & 3 & 3 & 3 & 3 & $\begin{array}{l}3 \\
2\end{array}$ & $\mathrm{~B}$ \\
\hline 5 & $\begin{array}{l}\text { Agil } \\
\text { Triya } \\
\text { din }\end{array}$ & 3 & 3 & 3 & 3 & 3 & 3 & 3 & 3 & 3 & 3 & 3 & $\begin{array}{l}3 \\
3\end{array}$ & B \\
\hline 6 & $\begin{array}{l}\text { Rosd } \\
\text { ania } \\
\mathrm{h}\end{array}$ & 3 & 3 & 3 & 3 & 4 & 3 & 3 & 3 & 3 & 3 & 3 & $\begin{array}{l}3 \\
4\end{array}$ & B \\
\hline 7 & $\begin{array}{l}\text { Alfiat } \\
\text { i }\end{array}$ & 3 & 3 & 3 & 3 & 2 & 3 & 2 & 3 & 4 & 3 & 3 & $\begin{array}{l}3 \\
2\end{array}$ & B \\
\hline 8 & $\begin{array}{l}\text { Ferni } \\
\text { awa } \\
n\end{array}$ & 4 & 4 & 3 & 4 & 4 & 3 & 3 & 3 & 3 & 3 & 4 & $\begin{array}{l}3 \\
8\end{array}$ & $A$ \\
\hline
\end{tabular}

Berdasarkan Tabel 3 maka dapat disimpulkan bahwa terjadi respon yang positif terhadap penggunaan Bahan Ajar Solusi Numerik Logika Fisika Berbasis Matlab Algoritm. Penggunaan bahan ajar ini memudahkan mahasiswa belajar Gui dan Sribs Matlab untuk kasus materi fisika dan membantu mahasiswa dalam memahami permasalahan numerik logika mahasiswa.

\section{Hasil Uji Coba Lapangan}

Uji coba lapangan dilakukan di Mahasiswa fisika Semester VI Program Studi Pendidikan Fisika Universitas Muhammadiyah Mataram Tahun Akademik 2018/2019. Untuk menentukan adanya pembentukan kemampuan solusi numerik logika Mahasiswa, dapat dilihat dari data soal yang diberikan sebelum penggunaan produk (pretest) dan setelah penggunaan produk (posttest). Berikut data rerata pemberian tes pada uji coba lapangan.

Tabel 4. Rerata Pretest dan Postest pada uji coba lapangan

\begin{tabular}{|c|c|c|c|}
\hline Item & Pretest & Postest & Gain standar \\
\hline Soal 1 & 555 & 650 & 0.4 \\
\hline Soal 2 & 550 & 615 & 0.3 \\
\hline Soal 3 & 585 & 660 & 0.3 \\
\hline Soal 4 & 575 & 640 & 0.3 \\
\hline Soal 5 & 575 & 635 & 0.3 \\
\hline
\end{tabular}

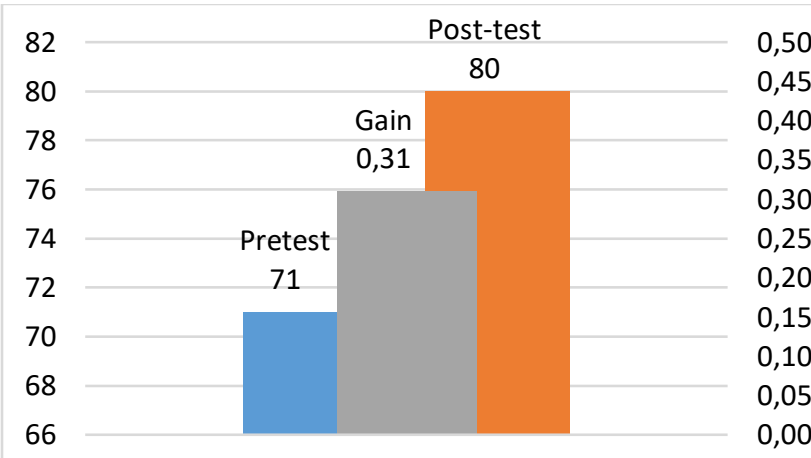

Hasil Peningkatan Kemampuan Solusi Numerik Secara Klasikal

Gambar 2. Grafik Hasil Peningkatan Kemampuan Solusi Numerik Secara Klasikal.

Berdasarkan Tabel 4, maka dapat disimpulkan bahwa terjadi peningkatan kemampuan solusi numerik logika mahasiswa. Peningkatan karakter yang paling besar pada item soal nomo 1 mahasiswa dapat memahami metedo bagi dua / regula falsi karena menentukan dua terkaan awal Suku pertama pada ruas kanan menyatakan gesekan tarik (friction drag), dan suku 
kedua menyatakan tekanan tarik (pressure drag).

Berdasarkan nilai $\mathrm{N}$-Gain yang berada pada rentang $0,7 \geq g \geq 0,3$, maka Kemampuan Solusi Numerik Logika mahasiswa mengalami peningkatan dengan kategori sedang. Hal ini karena mahasiswa mengalami kesulitan problema fisika ke dalam operasi matematika/ numerik.

\section{CAPAIAN LUARAN}

Luaran yang dihasilkan saat ini berupa Bahan Ajar solusi numerik logika yang telah divalidasi oleh ahli materi dan media, serta bahasa. Produk Bahan ajar disusun meliputi Scribs dan Gui Matlab untu kasus Fisika seperti pada lampiran.

Selanjutnya Produk yang dihasilkan akan dilakukan uji coba di Mahasiswa Program Studi Pendidikan Fisika Semester VI Tahun Akademik 2018/2019. Uji coba ini dilakukan untuk mengetahui kualitas bahan ajar solusi numerik logika.

Selanjutnya akan dilakukan publikasi penelitian pada jurnal ORBITA Volume 5 Nomor 1 November 2019 dengan p-ISSN:2460-9587 dan eISSN : 2624-7017. Dapat di download pada web: http://journal.ummat.ac.id/index.php/orbita/issue/vie w/85.

\section{SIMPULAN}

Berdasarkan hasil penelitian yang telah dilakukan, maka dapat disimpulkan sebagai berikut:

1. Berdasarkan hasil validasi ahli dapat disimpulkan bahwa produk bahan ajar solusi numerik logika mahasiswa yang telah dikembangkan telah layak untuk digunakan.

2. Berdasarkan hasil uji coba dapat diketahui bahwa produk yang dikembangkan memilki nilai tertimggi sebesar 0,31 pada kategori sedang .

\section{DAFTAR PUSTAKA}

Away, Gunadi Abdia. 2006. Matlab Progamming. Informatika. Bandung.

Arief dkk. 2012. Media Pendidikan Pengertian, Pengembangan Dan Pemanfaatan. Jakarta: Rajagrafindo Persada

Arikunto, S. 2010. Dasar-Dasar Evaluasi Pendidikan. Jakarta: Bumi Aksara

Arikunto, S. 2015. Dasar-Dasar Evaluasi Pendidikan. Jakarta: Bumi Aksara

Arsyad, A. 2017. Media Pembelajaran.Cetakan ke20. Jakarta: Rajagrafindo Persada

D. V. K. S. Roshni Tiwari, Sonal Sharma, "Emergence of Whitespace Technology for the Creation of Super Wi-Fi
Network", IJSRM, III (10), pp. 3592-3595, 2015.

Dimyati dan Mudjiono. 2009. Belajar dan Pembelajaran. Jakarta: Rineka Cipta

Emzir. 2014. Metode Penelitian Pendidikan Kuantitatif \& Kualitatif. Jakarta: Raja Grafindo Persada

Hake, R.R. 1998. Interactive-engagement versustraditional methods: A six-thousandstudent survey of mechanics test data for introductory physics courses. American Journal of Physics 66, 64 (1998). 10.1119/1.18809

Sabaryati, Johri., Isnaini, M, (2018). Pengembangan Media Pembelajaran Mekanika Berbasis Komputerisasi Untuk Membentuk Karakter IImiah Mahasiswa. ORBITA:Jurnal Kajian, Inovasi dan Aplikasi Pendidikan Fisika, 4(2), 52-55.

Mahmud. 2011. Metode Penelitian Pendidikan. Bandung: cv Pustaka Setia

Paranginangin, Kasiman. 2006. Pengenalan Matlab. Andi: Yogyakarta.

Sugiyono. 2013. Metode Penelitian Kuantitatif Kualitatif dan $R \& D$. Bandung: Alfabeta.

Sugiono.2016. Quantitative, Qualitative Research and R \& D Methods, Alfabeta, Bandung

Sugiyono. 2017. Metode Penelitian Kuantitatif Kualitatif dan $R$ \& $D$. Bandung: penerbit Alfabeta

S. Thiagarajan, D. S. Semmel dan M. I. Semmel. 1974. Instructional Development for Training Teachers of Exceptional Children: A Sourcebook. National Center for Improvement of Educational Systems DHEW/OE. Washington, D.C,

Sulistiyani, S, 2012. Touchscreen Delphi XE, Wahana Komputer, Semarang.

V. Ritu Sindhu, "Application and Research of Multimedia Technology in Modern Teaching", IJSRM, III (4), 2015.

Purwanto. 2016. Evaluasi hasil belajar. Yogyakarta: Pustaka Pelajar

Riduwan. 2014. Metode dan Teknik Menyusun Proposal Penelitian. Bandung: Alfabeta.

Uno B. Hamzah. 2016. Teori Motivasi \& Pengukuran. Jakarta: penerbit Bumi Aksara.

Zulmi, Nurul., Darmayanti, N.W.S., Zulkarnain., (2019). Pengembangan Rumfis (Rumus Fisika) Berbasis Program Matlab Pada Materi Suhu Dan Kalor Untuk Meningkatkan Motivasi Belajar Siswa SMPN 2 Labuapi Kelas VII Tahun Ajaran 2017/2018, ORBITA:Jurnal Kajian, Inovasi dan Aplikasi Pendidikan Fisika, 4(1), 8-20. 